\title{
ОСОБЛИВОСТІ ПЕРЕБГГУ ХРОНІЧНОГО ОБСТРУКТИВНОГО ЗАХВОРЮВАННЯ ЛЕГЕНЬ БЕЗ ПОЄДНАННЯ ТА В ПОЄДНАННІ З ТУБЕРКУЛЬОЗОМ У ПАЦІЄНТІВ ІЗ ЗАЛІЗОДЕФІЦИТНИМИ СТАНАМИ
}

\begin{abstract}
Резюме. Поєднання хронічного обструктивного захворювання легень (ХОЗЛ) та туберкульозу легень (ТБЛ) становить важливу медичну та соціальну проблему. Разом з тим, наявність залізодефіцитних станів (ЗДС) у цих хворих призводить до підвищення летальності та інвалідизації. Тож вивчення поширеності, статевих особливостей та клінічного значення ЗДС у хворих на ХОзЛ та чи без ТБЛ є актуальним.

Мета дослідження - вивчити особливості перебігу ХОЗЛ та поєднаної патології ХОЗЛ з ТБЛ у пацієнтів із ЗДС.

Матеріали і методи. Було обстежено 71 пацієнта із ХОЗЛ віком від 19 до 73 роки, з яких 36 мали ХОзЛ у поєднанні з ТБЛ. Усім хворим було проведено загальноклінічне обстеження, досліджували фрункцію зовнішнього дихання, а також показники якості життя і рівні тривожності та депресії.

Результати досліджень та їх обговорення. Було виявлено, що вік пацієнтів із ХОЗЛ був вищим, ніж при поєднаній патології ХОЗЛ та ТБЛ. У 55,8 \% осіб із ХОЗЛ та у 73,5 \% при поєднаній патології було діагностовано ЗДС. Звертає увагу, що у пацієнтів із ХОЗЛ анемія хронічних захворювань (АХЗ) була вірогідно рідше, ніж латентний дефіцит заліза (ЛД3), а при поєднанні ХОЗЛ та ТБЛ частка Хворих з АХЗ була більшою від частки пацієнтів із ЛдЗ. У пацієнтів із ТБЛ середні показники ШОЕ були вірогідно вищі, ніж у пацієнтів без ЗДС. У підгрупах із наявним ЗдС ОФВ був нижчим, ніж у пацієнтів без ЗДС. Звертає на себе увагу, що у хворих з поєднаною патологією та ЗдС рівні депресії та тривожності були вірогідно нижчими, ніж у пацієнтів без ЗДС, а показник якості життя (а саме психічний компонент здоров'я) був вірогідно вищим у хворих із поєднаною патологією та ЗДС.

Висновки. У пацієнтів із ХОЗЛ ЗДС було вірогідно рідше, ніж в осіб з поєднанням ХОЗЛ та ТБЛ. Як у хворих на ХОзЛ, так і в осіб із поєднанням ХОЗЛ та ТБЛ наявність ЗДС була пов'язана з нижчими рівнями ОФВ вищими показниками шОЕ та якості життя.
\end{abstract}

Ключові слова: хронічне обструктивне захворювання легень; туберкульоз легень; залізодефріцитні стани.

ВСтУП Однією з важливих медичних та соціальних проблем є поєднання ХОЗЛ та ТБЛ. За даними Всесвітньої організації охорони здоров'я, одна третина населення у світі заражена мікобактерією туберкульозу [1], а ХОЗЛ займає четверте місце у структурі смертності [2, 3]. ТБЛ підвищує ризик розвитку ХОЗЛ [4, 5], а ХОЗЛ, у свою чергу, сприяє розвитку ТБЛ [6]. За даними різних авторів, серед пацієнтів із ТБЛ ХОЗЛ виявляють у 4,1$87,2 \%$ [5]. Поєднання цих хвороб призводить до більш тяжкого ушкодження легень та більш значного запалення, що потребує тривалого лікування [4].

Усі хронічні інфекції, включаючи ХОЗЛ та ТБЛ, можуть спричинити анемії, серед яких частіше спостерігають анемії унаслідок дефіциту заліза [7]. Із ЗДС у пацієнтів 3 ХОЗЛ та ТБЛ діагностують залізодесріцитну анемію (ЗДА), АХЗ та ЛДЗ. При дисеренційній діагностиці ЗДА та АХЗ необхідно врахувати, що АХЗ характеризується легкою або помірною нормоцитарною гіпохромною анемією, а гіпохромія та мікроцитоз можуть бути у 20-30 \% випадків. Цей тип анемії пов'язаний зі зниженням рівня заліза в сироватці крові та відсотка насичення трансферину залізом (ВНТ3) і на відміну від ЗДА їй притаманний нормальний чи знижений показник трансферину [8]. ЛДЗ виявляють рідше, ніж анемії, і ще рідше лікують, але десріцит заліза навіть без анемії призводить до швидкого прогресування ТБЛ та ХОЗЛ, оскільки ЛДЗ пов'язаний із порушенням імунної фрункції та зниженням здатності контролювати іноекцію [9]. За літературними даними, поширення ЗДС у хворих на ХОЗЛ та ТБЛ дуже відрізняється, а саме, у пацієнтів із ТБЛ ЗДС спостерігають у 16-94 \% [10], а при ХОЗЛ - близько 15-30 \% [8, 11]. ЗДС як у Хворих на ХОЗЛ, так і в пацієнтів із ТБЛ можуть мати негативне прогностичне значення, пов'язане з підвищеною інвалідизацію та летальністю [10]. Необхідно додати, що статеві особливості перебігу зДС вивчені мало та результати досліджень $€$ суперечливими. За даними од- них досліджень, жіноча стать і старечий вік є фрактором ризику розвитку ЗДС при ТБЛ [10], за даними інших - чоловіча стать та шкідливі звички (тютюнокуріння, алкоголь, наркоманія) призводять до ЗДС [12].

Таким чином, поширеність, статеві особливості та клінічне значення ЗДС у хворих на ХОЗЛ в поєднанні та без ТБЛ залишаються не до кінця з'ясованими і потребують подальшого вивчення.

Метою дослідження було вивчити особливості перебігу ХОЗЛ та поєднаної патології ХОЗЛ та ТБЛ у пацієнтів із ЗДС.

МАТЕРІАЛИ І МЕТОДИ У досліджені ВЗяЛИ Участь 71 Хворий на ХОЗЛ, серед яких у 36 було діагностовано ТБЛ легень. До групи пацієнтів із ХОЗЛ ввійшло 12 жінок та 23 чоловіки віком $(54,3 \pm 2,3)$ року, до групи пацієнтів із поєднаною патологією ХОЗЛ та ТБЛ увійшло 11 жінок та 25 чоловіків віком $(41,9 \pm 2,1)$ року. В кожній групі відбувся поділ пацієнтів на підгрупи за наявністю ЗДС. Усім особам до та після лікування було проведено загальноклінічне обстеження із застосуванням клінічного (з детальним вивченням показників гемоглобіну, еритроцитів та гематокриту) та біохімічного аналізу крові (показники сироваткового заліза, трансфрерину та ВНТЗ), а також виконували тести САТ та МРС для оцінки впливу ХОЗЛ на загальний стан хворих [2], мікроскопію харкотиння; проводили дослідження фрункції зовнішнього дихання (комп'ютерна спірограсрія з бронходилатаційною пробою з сальбутамолом) та якості життя за допомогою опитувальника SF-36 [13]; проводили тест на тривожність Спілберга - Ханіна та тест на депресію А. Т. Бека [14]. Всі хворі отримували базисне лікування згідно з діючими протоколами.

Обчислення отриманих даних проводили з використанням програмного забезпечення Exel XP та прикладних програм STATISTICA 6.0.

РЕЗУЛЬТАТИ ДОСЛІДЖЕНЬ ТА ЇХ ОБГОВОРЕННЯ Було виявлено, що вік пацієнтів із ХОЗЛ був вірогідно 
вищим, ніж при поєднанні ХОЗЛ та ТБЛ (відповідно $(54,3 \pm 2,3)$ та $(41,9 \pm 2,1)$ року $(p<0,05)$, що не суперечить літературним даним [1, 15].

Аналізуючи показники крові ми виявили вірогідно вищі середні показники гемоглобіну, еритроцитів, гематокриту, сироваткового заліза та трансорерину в пацієнтів із ХОЗЛ порівняно з пацієнтами із поєднаною патологією (табл.).

Ми також виявили що ЗДС у хворих на ХОЗЛ зустрічалося вірогідно рідше (55,8 \%), ніж при поєднаній патології $(73,5 \%$, p<0,05). Необхідно також відмітити, що у пацієнтів із ХОЗЛ АХЗ була вірогідно рідше, ніж лдЗ (відповідно - 21,1 та 78,9 \% (p<0,05)), а при поєднанні ХОЗЛ із ТБЛ частка хворих на АХЗ була більшою від частки пацієнтів із Лдз (відповідно - 60 та $40 \%(p<0,05))$, що узгоджується з результатами дослідження, яке було нещодавно проведено в Бразилії [12].

Звертає на себе увагу, що ЗДС серед пацієнтів із ХОЗЛ було виявлено у 66,6 \% жінок і 52,2 \% чоловіків, а при поєднаній патології - у 66,6 \% жінок і в 71 \% чоловіків. Тобто хоч і не вірогідно, але при ХОЗЛ відсоток жінок із ЗДС був вищим, а при поєднаній патології, навпаки, нижчим.

Що стосується вираження запального процесу, середній показник ШОЕ був вірогідно вищим у пацієнтів із поєднаною патологією та ЗДС, ніж при поєднаній патології без ЗДС (відповідно $(41,9 \pm 3,6)$ та $(26,9 \pm 5,9)$ мм/год $(p<0,05))$, що узгоджується з літературними даними [12]. У пацієнтів із ХОЗЛ теж була відмічена така тенденція, але відмінності не були вірогідними. Необхідно зауважи- ти, що середній показник ШОЕ при ХОЗЛ був вірогідно нижчим, ніж при поєднаній патології (відповідно $(17,2 \pm 2,2)$ та $(37,3 \pm 3,2) \mathrm{мм} /$ год $(p<0,05))$.

Також було виявлено, що у підгрупах пацієнтів із ЗДС ОФВ ${ }_{1}$ був нижчим, порівняно з підгрупами без ЗДС відповідно в осіб із ХОЗЛ і при ХОЗЛ у поєднанні з ТБЛ та без ЗДС ОФВ пацієнтів 3 поєднанням із ЗДС - $(52,1 \pm 3,4)$ та $(30,9 \pm 1,9)$ $\%$, що не суперечить літературним даним [16].

Аналізуючи рівні депресії за тестом А. Т. Бека та тривожності за тестом Спілберга-Ханіна у пацієнтів із ХОЗЛ та ЗДС, порівняно з пацієнтами без ЗДС, вірогідної різниці виявлено не було. Натомість, хоча і не очікувано, ми виявили, що при поєднаній патології та ЗДС показники депресії та тривожності були нижчими, ніж у пацієнтів без ЗДС (відповідно рівні депресії - $(12,3 \pm 1,5)$ та $(22,3 \pm 4,9)$ бала $(p<0,05)$ та тривожності - $(40,6 \pm 1,7)$ та $(51,6 \pm 4,2)$ бала $(p<0,05))$. Варто зауважити, що у жінок та чоловіків з діагностованим ЗДС рівні депресії та тривожності були також нижчими, ніж у пацієнтів без ЗДС. Це знайшло підтвердження і при дослідженні якості життя, а саме, показників фрізичного (ФКЗ) та психічного компоненту здоров'я (ПКЗ), виявлено, що ПКЗ у пацієнтів із поєднаною патологією та ЗДС був вищим, ніж у хворих без ЗДС (відповідно $(58,9 \pm 2,4)$ та $(48,7 \pm 3,9) \%(p<0,05))$, ФКЗ був також вищим у пацієнтів із ЗДС, але не вірогідно. Таку ж тенденцію до вищих значень ФКЗ та ПКЗ ми спостерігали в групі хворих на ХОЗЛ, але не вірогідну.

Таблиця. Показники гемоглобіну, еритроцитів, гематокриту, сироваткового заліза та відсоток насичення трансферину

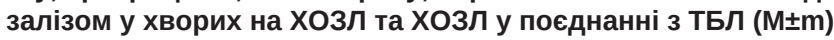

\begin{tabular}{|l|c|c|}
\hline \multicolumn{1}{|c|}{ Показник } & ХОЗЛ $(\mathrm{n}=35)$ & ХОЗЛ та ТБЛ $(\mathrm{n}=36)$ \\
\hline Гемоглобін (г/л) & $122,9 \pm 2,1$ & $143,7 \pm 4,1^{*}$ \\
\hline Еритроцити (х 1012/л) & $4,9 \pm 0,1$ & $3,9 \pm 0,2^{*}$ \\
\hline Гематокрит (\%) & $41,8 \pm 0,7$ & $35,7 \pm 0,9 *$ \\
\hline Сироваткове залізо (ммоль/л) & $10,6 \pm 0,6$ & $8,9 \pm 0,4{ }^{*}$ \\
\hline Трансфрерин (мг/дл) & $319,7 \pm 9,4$ & $211,2 \pm 7,5$ * \\
\hline ВНТ3 (\%) & $19,2 \pm 1,9$ & $18,5 \pm 1,1$ \\
\hline
\end{tabular}

Примітка. * - p<0,05 порівняно з групою хворих на ХОЗЛ.

ВИСнОВКИ На підставі проведеного дослідження виявлено, що вік пацієнтів був вірогідно вищий у хворих на ХОЗЛ порівняно з пацієнтами із ХОЗЛ у поєднанні 3 ТБЛ. Залізодесріцитні стани у хворих на ХОЗЛ виявляється вірогідно рідше, ніж при поєднаній патології. Необхідно відмітити, що при ХОЗЛ частка хворих із анемією хронічних захворювань була вірогідно нижчою, ніж із латентним дефріцитом заліза, а при поєднаній патології, навпаки, переважала анемія хронічних захворювань над латентним десіцитом заліза. У пацієнтів із ХОЗЛ у поєднанні та без ТБЛ при наявності залізодефіцитних станів ШОЕ була вірогідно вищою, ніж у пацієнтів без залізодесріциту, також показник ШОЕ був вірогідно нижчим при ХОЗЛ, ніж при поєднаній патології. У пацієнтів із залізодефіцитом ОФВ був меншим, ніж у пацієнтів без нього. Рівні депресії та тривожності були нижчими у хворих на ХОЗЛ та при поєднанні ХОЗЛ та ТБЛ із наявними залізодефіцитними станами, ніж у пацієнтів без них, а показник якості життя (а саме ПКЗ) був більшим у пацієнтів із залізодефріцитом порівняно з пацієнтами без нього.

Перспективи подальших досліджень Необхідним $€$ проведення подальших досліджень для кращого розуміння впливу ЗДС на перебіг ХОЗЛ в поєднанні та без ТБЛ і своєчасна цілеспрямована його корекція, а це, у свою чергу, може привести до значного поліпшення загального стану та прогнозу основного захворювання.

\section{СПИСОК ЛІТЕРАТУРИ}

1. World Health Organization. Global tuberculosis Control report. WHO report [Text] // WHO report. -2016 . -214 p.

2. Global Initiative for Chronic Obstructive Lung Disease (GOLD). Global Strategy for the Diagnosis, Management, and Prevention of Chronic Obstructive Pulmonary Disease. - 2014. - P. 93.

3. Miniño A. M. Deaths: Preliminary data for 2008 / A. M. Miniño,
J. Q. Xu, K. D. Kochanek // National Vital Statistics Reports. - 2010. - Vol. 59. - P. 2-8.

4. Ghimire H. B. Impact of pulmonary tuberculosis infection on chronic obstructive pulmonary disease / H. B. Ghimire, J. G. Li // European Respiratory Journal. - 2011. - Vol. 38. - P. 4070.

5. Диференційна діагностика бронхообструктивного синдрому 
у хворих на хронічне обструктивне захворювання легень у поєднанні з туберкульозом легень / М. Г. Бойко, Т. А. Сухомлин, Д. М. Бойко [та ін.] // Туберкульоз, легеневі хвороби, ВІЛ-інфекція. - 2011. - № 4(07). - С. 55-58.

6. Risk factors for pulmonary tuberculosis in patients with chronic obstructive airway disease in Taiwan: a nationwide cohort study / C. H. Lee, M. C. Lee, C. C. Shu [et al.] // BMC Infect. Dis. - 2013. - Vol. 13. - P. 194.

7. Weiss G. Pathogenesis and treatment of anaemia of chronic disease / G. Weiss // Blood Rev. - 2002. - Vol. 16. - P. 87-96.

8. Cullis J. O. Diagnosis and management of anemia of chronic disease: current status / J. O. Cullis // Br. J. Haematol. - 2011. Vol. 153(3). - P. 289-300.

9. Oppenheimer S. J. Iron and its relation to immunity and infectious disease / S. J. Oppenheimer // J. Nutr. - 2001. - Vol. 131. - P. 616-633.

10. Isanaka S. Iron deficiency and anemia predict mortality in patients with tuberculosis / S. Isanaka, F. Mugusi, W. Urassa [et al.] // J. Nutr. - 2012. - Vol. 142 (2) - P. 350-357.
11. Anemia in COPD and related factors / A. Fidan, M. Tokmak, N. Kiral [et al.] // Chest. - 2010. - Vol. 138. - P. 457.

12. Anemia in hospitalized patients with pulmonary tuberculosis / M. G. Oliveira, K. N. Delogo, H. M. Oliveira [et al.] // J. Bras. Pneumol. - 2014. - Vol. 40 (4). - P. 403-410.

13. Якість життя та прихильність до лікування в клініці внутрішніх хвороб : навч. посіб. / [В. І. Кривенко, І. С. Качан, С. П. Пахомова та ін.]. - 2015. - С. 27- 38.

14. Збірник методик для діагностики негативних психічних станів військовослужбовців : метод. посіб. / [Н. А. Агаєв, О. М. Кокун, І. О. Пішко та ін.]. - К. : НДЦ ГП ЗСУ, 2016. C. 97-129.

15. Tuberculosis and chronic respiratory disease: a systematic review / A. L. Byrne, B. J. Marais, C. D. Mitnick [et al.] // International Journal of Infectious Diseases. - 2015. - Vol. 32 - P. 138-146.

16. Nutritional deficits in elderly smokers with respiratory symptoms that do not fulfill the criteria for COPD / Y. Obase, K. Mouri, H. Shimizu [et al.] // Int. J. Chron. Obstruct. Pulmon. Dis. - 2011. -Vol. 6. - P. 679-683.

\section{FEATURES OF CHRONIC OBSTRUCTIVE PULMONOLOGY DISEASES WITHOUT COMBINATION AND IN COMBINATION WITH TUBERCULOSIS IN PATIENTS WITH IRON DEFICIENCY STATES}

Summary. The combination of chronic obstructive pulmonary disease (COPD) and pulmonary tuberculosis (TB) is an important medical and social problem. At the same time, the presence of iron deficiency states (IDS) in these patients leads to an increase in mortality and disability. Therefore, the study of the prevalence, sexual characteristics and clinical significance of IDS in patients with COPD and / or TB is relevant.

The aim of the study - to learn the features of the course of COPD and in combination of COPD with TB in patients with IDS.

Materials and Methods. 71 patients with COPD from 19 to 73 years of age were examined, 36 of which had COPD in combination with TB. All patients had a general clinical examination, spirometry, were tested for quality of life and a level of anxiety and depression. Results and Discussion. It was found that the age of patients with COPD was higher than with combined COPD and TB. $55.8 \%$ of patients with COPD and $73.5 \%$ of patients with combined pathology were diagnosed with IDS. It is worth noting that in patients with COPD, chronic anemia (CA) was found to be less likely than latent iron deficiency (LID), and when combined COPD and TB. Patients with acute respiratory viral hypertrophy were higher than the proportion of patients with LID. In TB patients, the mean ESR rates were significantly higher than in patients without IDS. In subgroups with available IDS FEV1 was lower than in patients without IDS. It is noteworthy that in patients with combined pathology and IDS a levels of depression and anxiety were significantly lower than in patients without IDS, and the indicator of quality of life (namely, the mental component of health) was significantly higher in patients with combined pathology and IDS.

Conclusions. Patients with COPD have been found to be less likely to have than patients with a combination of COPD and TB. Both patients with COPD and patients with a combination of COPD and TB, the presence of IDS was associated with lower levels of FEV1, depression and anxiety, as well as higher ESR and quality of life.

Key words: chronic obstructive pulmonary disease; pulmonary tuberculosis; iron deficiency states.

(СН. В. Жованик, М. И. Товт-Коршинская Ужгородский национальный университет

\section{ОСОБЕННОСТИ ТЕЧЕНИЯ ХРОНИЧЕСКОЙ ОБСТРУКТИВНОЙ БОЛЕЗНИ ЛЕГКИХ БЕЗ СОЧЕТАНИЯ И В СОЧЕТАНИИ С ТУБЕРКУЛЕЗОМ У ПАЦИЕНТОВ С ЖЕЛЕЗОДЕФИЦИТНЫМИ СОСТОЯНИЯМИ}

Резюме. Сочетание хронического обструктивного заболевания легких (ХОБЛ) и туберкулеза легких (ТБЛ) составляет важную медицинскую и социальную проблему. Вместе с тем, наличие железодесицитных состояний (ЖДС) у этих больных приводит к повышению летальности и инвалидизации. Поэтому изучение распространенности, половых особенностей и клинического значения ЖДС у больных ХОБЛ или без ТБЛ является актуальным.

Цель исследования - изучить особенности течения ХОБЛ и сочетанной патологии ХОБЛ с ТБЛ у пациентов с ЖДС.

Материалы и методы. Было обследовано 71 пациента с ХОБЛ в возрасте от 19 до 73 лет, из которых 36 имели ХОБЛ в сочетании с ТБЛ. Всем больным было проведено общеклиническое обследование, исследовали функцию внешнего дыхания, а также показатели качества жизни и уровни тревожности и депрессии.

Результаты исследований и их обсуждение. Было обнаружено, что возраст пациентов с ХОБЛ был выше, чем при сочетанной патологии ХОБЛ и ТБЛ. В 55,8 \% пациентов с ХОБЛ и в 73,5 \% при сочетанной патологии было диагностировано жДС. Обращает внимание, что у пациентов с ХОБЛ анемия хронических заболеваний (АХЗ) встречалась достоверно реже, чем 
латентный десрицит железа (ЛДЖ), а при сочетании ХОБЛ и ТБЛ доля больных с АХЗ была больше доли пациентов с лдж. У пациентов с ТБЛ средние показатели СОЭ были достоверно выше, чем у пациентов без ЖДС. В подгруппах с имеющимся ЖДС ОФВ уровни депрессии и тревожности были достоверно ниже, чем у пациентов без ЖДС, а показатель качества жизни (а именно психический компонент здоровья) был достоверно выше у больных с сочетанной патологией и ЖДС.

Выводы. У пациентов с ХОБЛ ЖДС было достоверно реже у пациентов с сочетанием ХОБЛ и ТБЛ. Как у больных ХОБЛ, так и у больных с сочетанием ХОБЛ и ТБЛ наличие ЖДС была связана с более низкими уровнями ОФВ ${ }_{1}$, депрессии и тревожности, а также с высокими показателями СОЭ и качества жизни.

Ключевые слова: хронические обструктивные заболевания легких; туберкулез легких; железодефицитные состояния. 